\title{
Crafting a $>$ Secret $<$ Space. Masonry and the Military in the Anglophone Caribbean
}

von

Allison O. Ramsay

\begin{abstract}
Freimaurerei und Militär waren in der englischsprachigen Karibik auf vielfältige Weise miteinander verbunden. Dies geschah insbesondere durch die Verbreitung der Freimaurerei über militärische Logen, welche als Regimentslogen dienten und auch nichtmilitärische Mitglieder aufnabmen und zivile Logen gründeten. Die kontinuierliche Verbreitung der Freimaurerei durch irische Freimaurer im Militär trug zum "Gendering" dieses maskulinen Raumes im karibischen Kontext bei. Der Dienst im Militär und die Mitgliedschaft in einer Freimaurerlage verdeutlichte die Zugehörigkeit zum Empire und verfestigte Begriffe von hegemonialer Maskulinität. Die Untersuchung der Verbindungen von Freimaurerei und Militär zwischen dem Ende des 18. Jabrhundert und dem frühen 20. Jahrbundert zeigt, dass beide, die Freimaurerei und das Militär einen großen Einfluss auf die kulturelle Identität, den Patriotismus und die Loyalität ibrer Mitglieder gegenüber den kolonialen Autoritäten hatten. Dieser Einfluss bestand bis über den Tod hinaus, wie die Epitaphe von einigen Freimaurern, die auf Barbados begraben wurden, belegen.
\end{abstract}

The gendering of space occurs in private and public spheres such as Freemasonry and the military. Some spaces such as English, Irish and Scottish Freemasonry are defined by a traditional physical exclusion of women. Gendered spatial divisions provide models for ways of extending spatial analysis to other forms of stratification and inequalities. This approach will be utilised to examine the interdependencies between organisations with secrets such as Freemasonry and, and its connection with the military from a trans-Atlantic perspective. This will be achieved by examining the military's role in establishing and promoting Freemasonry throughout the Anglophone Caribbean, particularly in the nineteenth century. I will also explore the connections of patriotism and allegiance to the British Empire through examples of men who were Masons who served in the military during the First and Second World Wars. This discussion is further enhanced by examining the importance of Masonry not only in life but in death by highlighting some of the Masonic iconography and epitaphs on monuments in one of the military cemeteries in this region, the Military Cemetery located at Needham's Point, St. Michael in Barbados to demonstrate how Masonic life was immortalised through specific iconography of the memory and cultural identity of the participants. In this way, I argue that through an examination of Freemasonry and the military in the space of the Anglophone Caribbean, between the end of the eighteenth and early twentieth century, both Masonry and the military had considerable influ- 
ence on cultural identity, patriotism and loyalty of its subjects and practitioners to colonial authorities.

\section{Space}

Space is connected to matters of the social relations of class, gender, and ethnicity. They are places of power, which are marked by contestations over their meaning. Power is both manifested and contested through space. Space and specific locations do not just provide a contextual background for social processes; they actively structure and mediate social action while continuously undergoing change through social action itself. ${ }^{1}$ Space changes based on context and space is not fixed. Therefore, it changes literally and physically. ${ }^{2}$ Power is both manifested and contested through space. Space can reveal the varied relationships between power and resistance and the ways in which culture is differentiated, fragmented, and contested. It must be emphasised though that the use and control of space are continuously negotiated. Therefore, power becomes spatialised. Moreover, space is integral in maintaining hegemony. ${ }^{3}$

There are many authorities on space such as Michel Foucault and Homi Bhaba. Foucault maintains that there are codes and a certain order in the allocation of space or the analysis of space. He focuses on another spatiality of social life, an external space. In his view, this is the actually lived and the socially produced spaces of sites and the relations between them. Edward Soja in "History, Geography, and Modernity « cites Foucault's position that space is fundamental in any exercise of power, ${ }^{4}$ and that space, knowledge, and power were related. According to Foucault:

It is somewhat arbitrary to try to dissociate the effective practice of freedom by people, the practice of social relations, and the spatial distributions in which they find themselves. If they are separated, they become impossible to understand. ${ }^{5}$

"Space is where discourses of power and knowledge are transformed into actual relations of power. $\aleph^{6}$ From Foucault's perspective, the idea of how power is created and becomes a reality can lead to the creation of hegemony and subordination.

1 Rivke Jaffe and Jolien Sanderse, »Surinamese Maroons as Reggae Artistes: Music and Marginality in Paramaribo, « Paper presented at International Symposium Urban Cultures of the Caribbean University of the West Indies, Mona, (27-29 Sept. 2007), pp. 1- 2.

2 Ibid.

3 Ibid.

4 Edward Soja, »History: Geography and Modernity, « Cultural Studies Reader 2 ${ }^{\text {nd }}$ Edition, ed. by Simon During (London, New York, 1993), p. 119.

5 Michel Foucault, Space, Knowledge, and Power. The Foucault Reader (New York, 1984), p. 246.

6 Johnson et al., p. 105. 
There are oppositional spaces and the questioning of dominant spaces, which has led to the production of marginal spaces such as the Third Space. "Studying the connections breaks down the idea of the inside and outside and opens what we would call a Third-Space. Not outside or inside but connected to both... « For Bhaba, the Third Space challenges »our sense of the historical identity of culture as [a] homogenising, unifying force... $\ll^{8}$ Investigating spaces and places tells us about the different ways in which meanings and power are tied together. It must be emphasised that space is continually constructed and reconstructed. ${ }^{9}$ The relations of power, the structures of inequality and the practices of domination and subordination are embedded in spatial relations..$^{10}$ The use of space will allow for an examination of the power barriers that fraternal societies assume and contest, that is, the divisions between hegemonic («above«) and counter-hegemonic («below «). ${ }^{11}$

For this writing, Doreen Massey’s views are most useful as she contends that space is a social construct. The social is spatially constructed. She states that »multiplicity and space are co-constitutive. " $^{12}$ In Massey's view, space is "a product of relations... and for that to be so there must be multiplicity. «13 For her, space as a social construct varies over time. ${ }^{14}$ While noting that the identities of places are always unfixed, contested and multiple, ${ }^{15}$ she asserts that space is implicated in questions of power and symbolism. Massey argues that space, place, and gender are interrelated in various ways because they are all culturally specific ideas. Therefore, the particular ways of thinking of space and place are tied up both directly and indirectly to the particular social constructions of gender relations. »Gender... [is] thoroughly saturated with power relations. Thus, it follows that the social construction of space will be gendered. $\ll^{16}$ She notes that gender relations vary over spaces, which are symbolically gendered.

The gendering of space is seen in both the public and the private. Some spaces such as Lodges are marked by the physical exclusion of particular sexes. The study of gender has been enriched by the ways that space contains, creates, and is constructed around gender relations. Gendered spatial divisions provide models for the ways of extending the spatial analysis to other forms of stratification and inequalities. ${ }^{17}$ Massey contends that $»$ the limitation of women's

Homi Bhabha, Nation and Narration (London, New York, 1994), p. 37.

Ibid.

9 Ann R. Tickamyer, »Space Matters! Spatial Inequality in Future Sociology, « Contemporary Sociology, 29 (Nov. 2000), 6, pp. 805-813.

10 Ibid.

11 Simon During, »Introduction, « Cultural Studies Reader $2^{\text {nd }}$ Edition, ed. by Simon During (London, New York, 1993), pp. 1-28.

12 Doreen Massey, For Space (London, 2005), p. 9.

13 Massey, For Space, p. 11.

14 Doreen Massey, »Introduction: Geography matters, « in Geography Matters, ed. by Doreen Massey and John Allen (Cambridge, New York, 1984), pp. 1-11.

15 Doreen Massey, Space, Place and Gender (Minneapolis, 1994), pp. 175-185.

16 Massey, Space, Place and Gender, p. 3.

17 Tickamyer, Space Matters, pp. 805-813. 
mobility in terms of both space and identity has been in some cultural contexts, a crucial means of subordination. $\ll^{18}$

Daphene Spain concurs with Massey's arguments on gender and space. According to Spain, »space is organised in ways that reproduce gender differences in power and privilege. ${ }^{19}$ She argues that spatial boundaries contribute to the unequal status of women. Spain further asserts that »spatial segregation is one of the mechanisms by which a group with greater power can maintain its advantage over a group with less power. $\ll^{20}$

\section{Freemasonry: a Gendered Space, Space of Exclusion}

One of the largest fraternal organisations in the world,

Freemasonry is a very old, secular, fraternal society which requires belief in a Supreme Being as its principal qualification for membership and which is dedicated to the practice of tolerance, respect and understanding of others; the encouragement of high standards of morality among its members; and the performance of charitable works. ${ }^{21}$

From the outset, the secrecy of the institution is the most important landmark of Freemasonry, which has existed from its »very origins. «»If divested of its secret character, it would lose its identity and would cease to be Freemasonry. «22

Based on its tradition on restrictions on the admission of women into Freemasonry, the organisation can be considered as a gendered space. These barriers must be explored in examining this gender exclusion. In the eighteenth century, the regulations of this sex-segregated institution were given more clout when in 1723, the UGLE published its first rulebook or Constitutions with the regulation that "no Bondmen, no Women, no immoral or scandalous Men« could join. ${ }^{23}$ Further, according to the >Basic Principles for Grand Lodge Recognition, < the membership of the Grand Lodge and individual Lodges shall be composed exclusively of men. Each Grand Lodge shall have no Masonic intercourse of any kind with mixed Lodges or bodies which admit women to membership.

These rules outlined the position of women, which mirrored the limited freedom of women in civic life and in the society of Europe at the time. In both instances, in the society and in the Lodge, there was spatial control, which led

Massey, Space, Place and Gender, p. 179.

19 Daphene Spain, Gendered Spaces (Chapel Hill, London, 1992), p. 233.

20 Spain, Gendered Spaces, p. 15-16.

21 W. Kirk Mac Nulty, Freemasonry: A Journey through Ritual and Symbol (London, 1994), p. 6

22 William H. Grimshaw, Official History of Freemasonry among the Colored People in North America (New York, 1997), p. 33.

23 «Women and Freemasonry: The Centenary, « Exhibition Guide. The Library and Museum of Freemasonry 4 June-19 Dec. 2008. The Library and Museum of Freemasonry (London 2008), p. 1. 
to the rise of sex-segregated spheres. Thus, spaces are symbolically gendered and some spaces such as Masonic Lodges have been marked by the physical exclusion of women. Freemasonry as a cultural product also has determined through its rules not only what a Mason should be, but what a man and a woman should be. In this realm, masculinities and femininities were subordinated based on the male Masonic criterion. The binaries of >them < and > us < were created. In so doing, this assisted in the construction of women based on their sex as the Other and contributed to a gendering of Masonry

These values which were embedded within the Lodges of Europe were transferred to the colonies of the British Empire. During the colonial era, there was an emphasis on maintaining the British colonial status quo. It was important to claim the identity of English although one lived in another geographical space, the Caribbean. Adhering to British culture through the traditions of Masonry in these Masons' perspectives would have ensured that the Lodges in the West Indies continued to be as regular and as authentic as the Lodges in their shomeland.< Thus, from the eighteenth century, an adherence to European values and the rules of Masonry perpetuated colonial notions of British superiority and, male hegemony in the societies of the Anglophone Caribbean.

\section{Spread of Freemasonry}

During the age of the British Empire, particularly between the eighteenth and early nineteenth centuries, Masonic sociability was on the rise in Britain. Military officers were particularly well represented in secret societies such as the Freemasons from the mid-eighteenth century in the Caribbean. In fact, the Masons of the military, along with colonists and Provincial Grand Masters (PGMs) were instrumental to the spread of Masonry in the British West Indies, particularly in the case of Irish Freemasonry. In adhering to the principles of Freemasonry, they too contributed to a gendering of spaces in the Anglophone Caribbean because the military and Freemasonry combined were the epitome of a dominant masculinity, they were spaces to which women could not belong.

Freemasonry was part of the »cultural baggage « of migrants as they moved into and out of the Caribbean. Freemasonry as an integral part of the migrants< »travelling culture « functioned as »imagined communities «Benedict Anderson contends that nations are »imagined communities «: they are »an imagined political community — and imagined as both inherently limited and sovereign. ${ }^{24}$ Anderson posits that »it is imagined because the members of even the smallest nation will never know most of their fellow-members, meet them, or even hear of them, yet in the minds of each lives the image of their communion. « ${ }^{25}$

24 Benedict Anderson, Imagined Communities, (London, 1983 [1991]), p. 6.

${ }^{25}$ Anderson, Imagined Communities, p. 6. 
Some of the oldest former colonies of the British Empire, Jamaica, St. Christopher (St. Kitts), Montserrat, Antigua, Barbados were the first places where Freemasonry had been established. Being part of the empire since the seventeenth century, the colonial ties between England and these colonies would have been stronger. Further, during the 1748 to 1815 period when early Lodges were founded, there was a new phase of British expansion in the Caribbean. The region was the main focus of national strategic effort. It was during this period that the West Indies achieved their greatest economic importance within the British Empire. ${ }^{26}$

Freemasonry has spread all over the world. A global Masonic network has been made possible through the roles of the naval and military personnel, colonists and the PGMs who were appointed to the Provincial Grand Lodges (PGLs). These were the principal categories of men who diffused Freemasonry throughout the empire. Commencing from the mid-eighteenth century, the British Grand Lodges appointed PGMs in the colonies wherever a strong Masonic presence had emerged, or wherever they had anticipated that Freemasonry would prosper. A PGM served as the Grand Lodge's representative in a locality. The PGM had the power to constitute new Lodges in his jurisdiction, which were then to be registered with the Grand Lodge. PGMs contributed to the spread and continuance of the Masonic global connections.

While Lodge meetings are normally held in fixed buildings, in order to allow regiments to remain faithful to their Freemasonry practices, travelling Lodges were established. These Lodges were also called >Field Lodges<, >Army Lodges<, and >Military Lodges. ${ }^{27}$ There were Naval or Sea Lodges too. The focus here is on the role of the military Lodges in disseminating Freemasonry in the British West Indies.

By developing the travelling warrant, Jessica Harland-Jacobs states that the Grand Lodge of Ireland (GLI) was instrumental to Freemasonry's spread throughout the world. Travelling warrants accompanied regiments and gave them the authority to hold Lodge meetings anywhere in the world. A warrant or Charter was a document issued by a Grand Lodge to indicate that it had granted members permission to form a Lodge. ${ }^{28}$

A travelling Lodge is one composed of Masons that travel from one site/ country to another. These Lodges were constituted in the regiments such as those of the British Army, permitting them to meet wherever the regiment was stationed and gave them the authority to hold Lodge meetings anywhere in the world. Robert Macoy adds that the Field Lodges were useful in relieving of the monotony of the soldier's life and mitigated the horrors of war. ${ }^{29}$ Although technically restricted to the members of the regiment, many of these Military

26 J.R Ward, »The British West Indies in the Age of Abolition, 1748-1815, « The Oxford History of the British Empire Vol. II, ed. P.J. Marshall (Oxford, New York, 1998), p. 415.

27 Robert Macoy, General History, Cyclopaedia and Dictionary of Freemasonry (New York 1994), p. 145.

28 Jessica Harland- Jacobs, »Hands across the Sea«: The Masonic Network, British Imperialism and the North Atlantic World in Geographical Review 89 (1999), pp.214.

29 Macoy, General History, p. 145. 
Lodges had initiated civilian candidates resident in the space where the Field Lodges met. When the regiment moved, the civilians would petition one of the Grand Lodges to be constituted as a stationary Lodge. ${ }^{30}$ This played an important role in the formation of Lodges throughout the world.

\section{Irish Military}

The military was particularly instrumental in carrying the banner of empire through Irish Freemasonry. Jamaica was also the first location where Irish Masonry was formalised in the Anglophone Caribbean. In the eighteenth century, Jamaica was responsible for the issue of four warrants to Lodges. These were the following: No. 456 in 1767; No. 699 in 1789 and Nos.733 and 738 in 1791. F.W. Sealcoon states that although the Irish military and other warrants were used by the GLI since 1732, there is no record of Irish Lodges working in Jamaica until $1795 .{ }^{31}$ In his assessment of the contribution of Irish Freemasonry to Jamaica, Sealcoon asserts:

the early history of Irish Lodges in Jamaica is somewhat surrounded by an Irish mist and owing to their mainly military nature, they and their incidence bear no particular relation [neither] to the island's economy nor to its history except ... in the almost continual wars of that time..$^{32}$

Sealcoon's writing on the early Irish Lodges in Jamaica notes the military importance of the Irish, which was essential to the movement of Masonry in the region.

A study of Masonry is also one of maritime history. The spread of this »travelling culture « which is part of the naval and maritime history of Europe and the Caribbean demonstrates an intersection, overlap, and conflict across different channels of power and identity. For example, in the Caribbean on March 4,1752 , the GLI granted a warrant to the $46^{\text {th }}$ Regiment. The Lodge was a regimental one, which accompanied the $46^{\text {th }}$ through all of its campaigns. For instance, in 1761, it embarked for Barbados; was in service in Havana in 1762, and returned to the American Continent in 1764. It remained in some of the English colonies to the south of Canada for four years. ${ }^{33}$ Thus, such evidence of the naval and maritime history of cultural encounters, marine mobility and Freemasonry were visible in the region.

30 John Hamill, The History of English Freemasonry (Surrey, 1994), p. 97.

31 Frederic William Sealcoon, An Historical Account of Jamaican Freemasonry (Kingston, 1976), p. 19.

32 Ibid.

33 P.G. Sec. Bro. F.C. Crossle, »Extracts from an address delivered at a Communication of the Provincial Grand Lodge of Down, «11 Feb. 1896. Keith Cochrane (comp.) Irish Masonic Records: Second CD Edition CD-ROM (Ireland: Grand Lodge of Ireland, 1973). 
The Irish military contributed to the cultural flow of Freemasonry in colonies that were ruled by the French. With the spread of Masonry in the Caribbean, the region was a space without borders. The history of the Lodge No. 690 is an example of a Regimental Lodge settling down as a Civilian Lodge abroad. It was warranted in the year 1788 in the $51^{\text {st }}$ Foot, which was established at Fort Royal, Martinique on April 2, 1801. The brothers "Jas Hanna, « Charles Ferguson « and Wm. Kirby« originally petitioned the Lodge No. 690 with the request to hold a Lodge in the $51^{\text {st }}$ Regiment of Foot, which was granted on September 4, 1788. ${ }^{34}$ The three men previously mentioned were registered on the same date. There was no registration of a Master or Wardens but these three likely held these positions. Although the Lodge assumed a civilian status, this Lodge retained its wanderlust and shifted its quarters to Trinidad by $1807 . .^{35}$

Barbados's significance in the origins and development of Masonry in the Anglophone region is seen when it became the second Caribbean territory where Irish Freemasonry was established in the year 1783. Irish Lodges continued to spread across the Caribbean to places such as St. Lucia, Guyana, Martinique, Grenada, Bermuda and Trinidad. It must be acknowledged though that not all Irish Lodges were established by travelling Lodges attached to regiments. John Lepper and Philip Crossle provide an explanation for the flourishing of Irish Freemasonry from the eighteenth century due to trade in the colonial era.

The fact may be recalled that in those days, the town of Cork was the usual last port of call for British vessels bound to the West Indies and it was only natural that one or two Irish warrants should find their way across the Atlantic together with salted beef and whiskey which, from the days of Raleigh onwards, had formed no inconsiderable portion of the cargo of ships outward bound from our southern ports. ${ }^{36}$

There was a substantial amount of trade between the colonies of the West Indies and Ireland. Table 1.1 shows that there were nine locations in the West Indies where Irish Lodges had been established in formative years. Barbados had the highest number of Irish Freemasonry, that is, seven followed closely by Jamaica and Bermuda with six and five respectively. Thus, there was an early Irish Masonic dominance in Barbados.

Minutes of Grand Lodge of Ireland, Lodge No. 690. 4. Sept. 1788, GLI.

Cochrane (comp.) Irish Masonic Records: Second CD Edition.

36 John Heron Lepper and Crossle, History of the Grand Lodge of the Free and Accepted Masons of Ireland Vol. 1 Lodge of Research CC (Dublin, 1925), pp. 242-243. 
Table 1.1 Early Irish Lodges in the Caribbean.

\begin{tabular}{l|l|l} 
Location & Lodge No. & $\begin{array}{l}\text { Total } \\
\text { Lodges }\end{array}$ \\
\hline Barbados & $\begin{array}{l}222 ; 259 ; 277 ; 282 ; 653 ; 622 ; \\
649\end{array}$ & 7 \\
\hline Castries, St. Lucia & 223 & 1 \\
\hline Demerara & 887 & 1 \\
\hline Fort Royal, Martinique & 690 & 1 \\
\hline Grenada & $224 ; 252$ & 2 \\
\hline Hamilton and St. George's Bermuda & $123 ; 580 ; 209 ; 220 ; 224$. & 5 \\
\hline $\begin{array}{l}\text { St. Jaego, Port Royal and Kingston, } \\
\text { Jamaica }\end{array}$ & $35 ; 390 ; 456 ; 699 ; 738 ; 733$ & 6 \\
\hline Trinidad & 690 & 1 \\
\hline Martinique & 690 & 1
\end{tabular}

Grand Lodge of Freemasons of Ireland Membership Register Series 2 Vols. 2 and 4, GLI. Grand Lodge of Freemasons of Ireland Membership Register Series 1 Vol. 3, GLI. Keith Cochrane (comp). Irish Masonic Records: Second CD Edition. CD-ROM. (Ireland: Grand Lodge of Ireland, 1973).

Secret networks continued to exist within the military in the Caribbean well into the nineteenth century. For instance, the Ninth regiment of Foot at Fort Charlotte, St. Vincent, West Indies was warranted Lodge No. 183/221 installed at Plymouth Dock in England was meeting in the capital of St. Vincent, Kingstown in 1819. The regiment is then recorded as having their Lodge meetings between 1819 and 1824 in Richmond Hill, Grenada in a private room. ${ }^{37}$ This Lodge of course was initiating civilians in that space along with its own as there were 159 members recorded whose occupations ranged from captain, merchant, pilot, seamen, surgeons to a sergeant in the $9^{\text {th }}$ Regiment. Members originated from places such as Ireland, Scotland, Liverpool, Gibraltar, New York and Montreal. ${ }^{38}$

Another military Lodge that existed in the Caribbean during the nineteenth century was Lodge No. 290 held in His Majesty's $85^{\text {th }}$ Regiment. They too were initiating civilians and spreading Masonry in this space. In the list of members returned to the Grand Lodge between 1801 and 1808, there were thirty members. Their professions seemed very working class and ranged from weaver, stonemason, shoe maker, watchmaker, painter, bricklayer to miller. ${ }^{39}$ In 1803,

37 Proceedings of Lodge No.183 commencing 30 Jan. 1800. GBR 1991 ELM/ 1298; A9/96, pp. 158-215.

38 Rules and Regulations of the Worshipful Lodge No.183 No. 221 of the Most Ancient and Honorable Fraternity of Free and Accepted Masons of England. According to the Old Constitutions held in His Majesty's Ninth Regiment of Infantry. To which is added a list of members by Brother E. Butler. W. Master 1806. GBR 1991/ELM/1298; A9197.

39 List of the Members of the Lodge No.290 Held in His Majesty's $85^{\text {th }}$ Regiment and returned to the Grand Lodge the 22 January 1809. SN1379/V, United Grand Lodge of England. 
in a letter from the Worshipful Master, Peter Connell to Robert Leslie Esq. of the Grand Lodge we get a glimpse of what the soldiers experienced at Stony Hill, Jamaica. There were 25 names on the list at the time.

We are stationed nine miles to the [...] of Kingston in the midst of [...] mountains surrounded on every side by negroes Huts and [...] of habitation only the [...] Barracks which $[\ldots]$ are quartered $[\ldots]$ Therefore $[\ldots]$ we are in the desolate part of the world $[\ldots]$ but we hope to be the way that $[\ldots .$.$] the happiness of making all their$ inconveniences $[\ldots]$ in old England. ${ }^{40}$

Fifty names were on the list of members of Lodge No. 290 held in His Majesty's $85^{\text {th }}$ Regiment Quartered at Kingston Barracks in Jamaica in 1807. Yet twenty-one, were deceased in Jamaica between 1805 and 1806, one soldier was transferred to $55^{\text {th }}$ Regiment and another to $6^{\text {th }} \mathrm{Br}$. 60 Regt. ${ }^{41}$

From the eighteenth century, well into the nineteenth century, men of the military contributed to the crafting of masonic networks in the Anglophone Caribbean through establishing Lodges or by continuing to practice the Craft in travelling Lodges attached to their regiments. Therefore, there was a significant presence and role and contribution that these Masons in the military played in relation to the creation of a Masonic culture in the history of Freemasonry during the period of empire.

\section{Masons Fight in the First and Second World Wars}

Into the twentieth century, the presence of Masons in the military in the British West Indies is made visible. Fighting for the British Empire was a significant way in which the relationship between the colonies and its Mother Country was defined. Being a soldier and a Freemason was the height of service to Britain. During the First World War, all of the Lodges under the Barbados District $»[. .$.$] furnished from their ranks members loyally serving King and$ country. «2 The First World War »was accepted with great patriotic fervour. «33 Some of Masons in the Caribbean who served in the military during the First World War were from the English Constitution Lodges, namely the Albion Lodge No. 196, St. Michael Lodge No. 2253 and Victoria Lodge No. 2196 of Barbados; Abercrombie Lodge No. 2788 of St. Lucia and St. George Lodge No. 3072 of Grenada. They served predominately in the British West Indies

40 Peter Connell, Worshipful Master Lodge No.290 Letter to R. Leslie, Esq. 2 June 1803. GBR 1991 SN1379/1. Henry Frederick, Duke of Cumberland, Grand Master of the Moderns Grand Lodge, 22 Sept. 1785. GBR 1991.

41 John Daft, Worshipful Master Lodge No. 290 Letter to Thomas Leslie Esq. 11 July 1807. GBR 1991 SN 1379/11.

42 District Grand Lodge of Barbados under the United Grand Lodge of Ancient Free and Accepted Masons of England Proceedings of the $84^{\text {th }}$ regultant $29^{\text {th }}$ annual communication $19^{\text {th }}$ July 1918 holden at the Masonic Hall Spry Street, B'town, 10 n.p.

43 St. Michael's Lodge Centenary Yearbook 1888-1998, (Bridgetown: Privately Published), p. 34. 
Regiment. Some of the other regiments were unknown, while others included the London Regiment, the Cadet Air Service and the Royal Navy. The majority was Master Masons and a few were Past Master Masons. Their ranks included Lieutenants and Sergeants for the most part and three were captains.

In total, thirty-five Masons from Barbados and the Eastern Caribbean served in the First World War. From Barbados, fourteen were Masons in Albion Lodge No. 196; five were from Victoria Lodge No. 2196 and ten were from St. Michael's Lodge No. 2253. Of the thirty-five Masons from Barbados and the Eastern Caribbean, one died of wounds, John Carleton Manning, Master Mason of St. Michael's Lodge No. 2253 E.R. ${ }^{44}$ Elsewhere in the Eastern Caribbean, nineteen Masons from the Abercrombie Lodge in St. Lucia, seven were from St. George Lodge, Grenada and undisclosed number were from St. George Lodge No. 2616, St. Vincent. Also in Jamaica, for instance, sixty-four members of the Irish Lodge South Carolina Lodge, $1^{\text {st }}$ West India Regiment No. 390 held in Jamaica served in the 1914-18 war.

The son of a Worshipful Brother R.H. Hinds Walcott who was a Past District Grand Warden was killed in action on a British submarine. For this, a vote of condolence was recorded to sympathise with Walcott on the »death of his son who died nobly fighting for his King and his country. $\ll^{45}$ Nine of the Masons in the South Carolina Lodge died during World War One. These men have made their mark in the region «s history as those who have died, their names are among those inscribed in cenotaphs in the Caribbean and, Manning and Walcott's names are also on the Roll of Honour 1914-1918 at the Military Cemetery. When World War One was over, it was remarked that »the British Empire has once again played a glorious part in a fight for victory and with her allies has triumphed. «In London, Lodges under the English Constitution were invited to subscribe towards the cost of the building of the Masonic Million Memorial Temple in memory of those Masons who paid the ssupreme sacrifice. ${ }^{46}$ This was a vital component of hegemonic masculinity since to be a Mason and serve empire would have been a benchmark of male pride.

\section{THE MILITARY CEMETERY}

The Military Cemetery is an ideal location chosen to investigate the cultural practice of highlighting that some men of the military were Masons through iconography and epitaphs bearing in mind that in the past, there were travelling Lodges.

Upon visiting the Military Cemetery in 2011, I observed that there were four monuments with identifiable Masonic symbols in the Military Cemetery. Three of them can be attributed to a Staff Sergeant, an Engine Room Artificer and a Captain's Steward. There is another which shows many of the symbols of Masonry as well but no identifiable name. Nonetheless, these headstones demonstrate how Masonry was a transnational network which connected men

${ }_{44}$ District Grand Lodge of Barbados under the United Grand Lodge of Ancient Free and Accepted Masons of England Proceedings of the $84^{\text {th }}$ regultant $29^{\text {th }}$ annual communication $19^{\text {th }}$ July 1918 holden at the Masonic Hall Spry Street, B'town, 11.

45 Ibid., p. 15.

46 Ibid., p. 2. 
throughout the British Empire not only through life but in death. It is important to provide descriptions and transcriptions of these monuments to illustrate this point.

\section{Staff Sergeant W. E Pettifer}

At the top of the headstone of Staff Sergeant W. E Pettifer are the Masonic symbols square and compass with the letter $>G$ < in the middle, at the bottom, the popular Masonic motto, »Let Brotherly Love Continue.« The epitaph states:

ERECTED BY ROYAL STANDARD LODGE/ OF/ A.F. \& A.M.NO.398 R.E. / HALIFAX N.S. / IN MEMORY OF STAFF SERGT. W.E. PETTIFER/ MILY. STAFF CLERK/DIED AUG. 25. $1880 /$ AGED 33 YRS. \& 8 MOS. / LET BROTHERLY LOVE CONTINUE/ C.A. SANFORD/HALIFAX, NOVA SCOTIA.

Since erected by the Royal Standard Lodge No. 398, it indicates that Pettifer was likely a member of the Royal Standard Lodge No. 398, Royal Engineers of Halifax, Nova Scotia.

\section{George William Spencer}

To the left side of the cemetery by the wall is the final resting place of George William Spencer, Engine Room Artificer. At the top of the gravestone is the square and compass. The inscription reads:

IN MEMORY OF GEORGE WM SPENCER/ ENGINE ROOM ARTIFICER/ H.M.S »MAGICIENNE«/ DIED AT BARBADOS/ 22 MARCH 1893/AGED 40/ ERECTED BY HIS MESSMATES.

It is plausible that there may have been a travelling Lodge aboard this ship since this monument was erected by Spencer's messmates. William WardDirectly behind Spencer's grave is that of Captain's Steward, William Ward. Also seen at the top of his gravestone is the square and compass.

His epitaph states:

CAPTAINS STEWARD/H.M.S. CANADA/ BORN AT MINSTER SHEERNESS/24 ${ }^{\mathrm{TH}}$ MAY 1852/ DIED AT BARBADOS/ $6^{\mathrm{TH}}$ NOVEMBER 1892/GREATLY REGRETTED.

Predominately, the symbols chosen to elucidate this Masonic connection in the burial grounds that were explored were the square and compass, the universal symbol of Freemasonry. These headstones indicate that that these men were not born in Barbados but were stationed here. Connections across the Atlantic are also visible in the graveyards with mentions of countries such as Canada on the epitaphs in Barbados. Their final resting place at the Military Cemetery was selected because this is likely where they were stationed in the cases of Ward and Spencer. Perhaps, Pettifer was also stationed here or was nearest to Barbados when he died. Furthermore, offices these men held were not of the highest rank.

Gravestones or headstones tell us about the ages of those who died their sex, their social position, and sometimes the cause of death. Inscriptions on these funerary ornaments also tell us about people's beliefs. By commemorating 
these Masons in this way, those who mourn them choose to identify them with a particular cultural and collective identity. The sharing of these symbols continues a link between Masons in death and this is done by the living who understand that the symbols shared are part of a sense of who and what they are, that is to say a Freemason. This brief exploration of the cultural practice of commemorating Masons through inscriptions and iconography is important to an understanding of the connections between Freemasonry, mortuary practices and the socio-spatial landscape of eighteenth and nineteenth century Barbados.

\section{Summary}

It has been argued that Masonry and the military were interconnected in the space of the Anglophone Caribbean in several ways namely through the transmission of Freemasonry by military Lodges which functioned as regimental Lodges that initiated civilians or established civilian Lodges. The continued spread of Freemasonry by Irish Masons in the military contributed to the gendering of this masculine space in the Caribbean context. I argue that serving in the military and being a Freemason signified an allegiance to empire and cemented notions of hegemonic masculinity. I have also shown the importance of Masonry to men in the military in life through their dissemination of Freemasonry in the Caribbean and depicted its importance in death as well through highlighting some of the Masonic iconography on the monuments of men of the military who were Masons buried in the Military Cemetery in Barbados. 